Joanna Karczewska*

Kielce

\title{
Chrześcijańskie zasady wychowania w świetle koncepcji Stefana Kunowskiego ${ }^{* *}$
}

Podstawowe zasady w pedagogice oznaczają zbiór reguł niezbędnych w procesie edukacji człowieka. Te ogólne prawidła działania „obowiązują wszystkich wychowawców, niezależnie od dziedziny wychowania. Płyną one z podwójnego źródła. Jednym jest cel końcowy wychowania, ideał nowego człowieka, do którego wszechstronny rozwój natury ma doprowadzić. Drugim źródłem zasad wychowania jest naukowa znajomość wychowanka i praw jego rozwoju"1. Wynikają więc one z nauki o celach i przedmiocie wychowania.

W edukacji chrześcijańskiej, czerpiącej ze stale unowocześnianej doktryny wychowawczej Kościoła, zasady wychowania nazywa się doktrynalnymi ${ }^{2}$. Występują one łącznie, dążąc do podwójnego celu - nadprzyrodzonego (zbawienie) i doczesnego (dobro osoby i społeczności) ${ }^{3}$. Wyróżniamy wśród nich dwie grupy zasad: kierownicze (ideowe) oraz realizacyjne (praktyczne). Drugie zapewniaja

${ }^{*}$ Dr Joanna Karczewska, adiunkt w Instytucie Edukacji Szkolnej Akademii Świętokrzyskiej w Kielcach.

** Stefan Kunowski ur. 20 VI 1909 r. studiował na Wydziale Nauk Humanistycznych KUL, gdzie uzyskał tytuł magistra filologii polskiej (1934) oraz magistra filozofii w zakresie pedagogiki (1937). Tutaj też doktoryzował się w 1945 r., habilitował się w 1951 r., a w 1977 r. uzyskał tytuł profesora nadzwyczajnego. Pracował m.in. na Wydziale Nauk Humanistycznych i Wydziale Filozofii Chrześcijańskiej KUL oraz w Diecezjalnym Seminarium Lubelskim. Działał w Towarzystwie Naukowym KUL. Zmarł w Lublinie w 1977 r. Artykuł ten poświęcony jest pamięci S. Kunowskiego w 30. rocznicę jego śmierci.

${ }^{1}$ S. Kunowski, Podstawy pedagogiczne rozwijania życia wewnętrznego, w: Bielski T. (red.), Ku odnowie życia wewnętrznego, Poznań-Warszawa 1972, s. 95-96; por. tenże, Podstawowe zasady wychowania w Deklaracji, Ateneum Kapłańskie, R. 60: 1968, nr 359, s. 414; tenże, Podstawy wspótczesnej pedagogiki, Warszawa 2001, s. 98.

${ }^{2}$ Por. tenże, Podstawowe zasady wychowania..., s. 421.

${ }^{3}$ Por. tamże, s. 423. 
skuteczność wychowania, wypływają „,z mądrości wychowawczej, doświadcze-

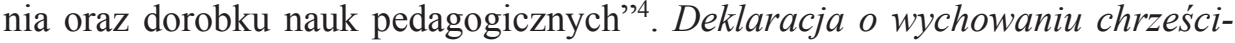
jańskim przedstawia cztery zasady praktycznej realizacji. Zasada postępu naukowego (a) wykorzystuje najnowsze zdobycze pedagogiki i psychologii. Zachęca do poszukiwań w doborze programów i metod wychowania, do posługiwania się nowoczesnymi środkami dydaktycznymi. Dotyczy ona zarówno szkół katolickich, jak i świeckich. Zasada adaptacji do wspótczesności (b) wiąże edukację z nauka, kulturą oraz pracą socjalną. Zasada pomocniczości (c) natomiast zobowiązuje państwo i Kościół do wielostronnego wspomagania rodziców i wychowawców. Postuluje też tolerancję i wolność sumienia. Zasada współdziałania (d) państwa, Kościoła, szkoły i rodziny zaleca różnorodne formy pracy zmierzającej do wspólnych celów5 5

Z ostatecznego celu człowieka (idei naczelnej) oraz z przedmiotu wychowania (wszechstronnego rozwoju i duchowej przemiany natury) wywodzą się propagowane przez S. Kunowskiego kierownicze zasady wychowania. Nie różnią się one od zasad całego chrześcijaństwa, gdyż ukształtował je i przekazał na kartach Ewangelii Syn Boży ${ }^{6}$. Dlatego centralne miejsce wśród nich, jako źródło i duch pozostałych zasad, zajmuje chrystocentryzm ${ }^{7}$. On to wraz z moralizmem wiąże się z nadnatura. Obydwie zasady wspólnie apelują do dobrej woli człowieka. Personalizm i humanizm wynikają z ludzkiej natury stworzonej na wzór Boga, do którego prowadzą. Skierowane są do rozumnej, wolnej osoby jako istoty społecznej ${ }^{8}$.

Zasady te przepajają wszystkie dokumenty soborowe, których celem jest odnowa chrześcijańska wiernych. Wprowadzają i rozwijają ducha Jezusa Chrystusa - miłość, szacunek ,oraz apostolską aktywność wraz z czynnym miłosierdziem i współczuciem dla ludzkich potrzeb" ". Chrystocentryzm bowiem, łącząc w sobie prawdy wiary, przedstawia cel - ideał nowego człowieka. Moralizm, poprzez etyczne oddziaływanie na wychowanka, wskazuje drogę do tego celu. Personalizm mówi o istocie człowieka jako osoby. Humanizm zaś, biorąc pod

${ }^{4}$ Tamże, s. 421; por. tenże, Podstawy pedagogiczne rozwijania..., s. 96.

${ }^{5}$ Por. tenże, Podstawowe zasady wychowania..., s. 423-424.

${ }^{6}$ Por. tenże, Podstawy wychowania duszpastersko-katechetycznego, Katecheta, R. 6: 1962, $\mathrm{nr} 4$, s. 210; tenże, Wychowanie autentycznego człowieka w seminarium duchownym, Colloquium Salutis, t. 5: 1973, s. 197.

${ }^{7}$ Por. tenże, Teologia a potrzeby pedagogiki katolickiej, AK, R. 51: 1959, nr 300/302, s. 240; tenże, Podstawy wychowania..., s. 213; tenże, Założenia i aktualne potrzeby wychowania katolickiego, AK, R. 54: 1962, nr 323, s. 227.

${ }^{8}$ Por. tenże, Podstawy pedagogiczne rozwijania..., s. 96; tenże, Ogólne wskazania katechetyczne, Kat, R. 12: 1968, nr 12, s. 146; tenże, Zakony w Polsce. Ksztaltowanie się idei duszpastersko-wychowawczych w Polskim Tysiacleciu, Miesięcznik Diecezjalny Gdański, R. 10: 1966, nr 9-10-11, s. 498.

${ }^{9}$ tenże, Podstawy współczesnej..., s. 104; tenże, Idee duszpastersko-wychowawcze w polskim tysiacleciu [rps], Lublin 1966, s. 14; tenże, Dekret o formacji kapłańskiej i jego znaczenie dla nowicjatu zakonnego [rps], Lublin 1971, s. 11. 
uwagę dobro całej ludzkości, stanowi o czynie człowieka dla człowieka ${ }^{10}$. Synteza tych zasad tworzy nierozerwalną całość. Ich stosowanie jest „autentycznym działaniem chrześcijańskim" ${ }^{11}$ w wychowaniu współczesnego człowieka. Daje „pewność i gwarancję właściwej realizacji i pełnego rozwoju” ${ }^{12}$ koncepcji integralnej edukacji.

\section{Chrystocentryzm punktem wyjścia współczesnego wychowania}

Zbawcza misja Chrystusa stanowi centrum Dobrej Nowiny, „albowiem Bóg nie posłał swego Syna na świat po to, aby świat potępił, ale po to, by świat został przez Niego zbawiony" (J 3, 17) ${ }^{13}$. Naukę tę uobecniają Ewangelia i Eucharystia, które stanowią wzór miłości, dobroci i cnót chrześcijańskich, dają naśladowcom przykład życia. Wynika z nich zasada chrystocentryzmu oparta na wierze w Jezusa Chrystusa i w Jego Objawienie. Jest ona naczelną zasadą wychowania człowieka religijnego żyjącego w Kościele i we wspólnotach z nim związanych ${ }^{14}$.

Chrystocentryzm promieniuje na całe życie chrześcijańskie. Teologiczne wyjaśnienie tej zasady oparte jest zarówno na Starym, jak i Nowym Testamencie („Badacie Pisma, ponieważ sądzicie, że w nich zawarte jest życie wieczne: to one właśnie dają o Mnie świadectwo” - J 5, 39; „Podczas gdy Prawo zostało nadane przez Mojżesza, łaska i prawda przyszły przez Jezusa Chrystusa" - J 1, 17). Szczególnie thumaczą ją słowa: „Jeden jest tylko wasz Mistrz - Chrystus” (Mt 23, 10), który mówi o sobie: „Ja jestem drogą i prawdą i życiem” $(\mathrm{J} 14,6)^{15}$. Posłany przez Ojca, by objawić najgłębsze prawdy o Nim, staje się Pośrednikiem między ludźmi a Bogiem (J 14, 6). Wskazuje im drogę do Pana. Jako sprawca i „brama” zbawienia stoi w obronie Jego pierwotnego planu ${ }^{16}$. Chrystus jest Bogiem wśród nas („Oto Dziewica pocznie i porodzi Syna, któremu nadadzą imię Emmanuel, to znaczy «Bóg z nami»» - Mt 1, 23) oraz przyczyną każdej łaski (,,aby wszystko dał wam Ojciec, o cokolwiek Go prosicie w imię moje” - J 15, 17). „W Jego misterium paschalnym znajdujemy szczyt i źródło chwały Bożej”'17.

${ }^{10}$ Por. tenże, Problematyka współczesnych systemów wychowania, Kraków 2000, s. 67-68; tenże, Podstawy wychowania..., s. 212-213; tenże, Podstawy współczesnej..., s. 98.

${ }^{11}$ Tenże, Podstawy wychowania..., s. 213.

${ }^{12}$ Tenże, Wychowanie do odpowiedzialności spolecznej, CS, t. 1: 1969, s. 74.

${ }^{13}$ Por. tenże, Podstawy wychowania..., s. 210.

${ }^{14}$ Por. tenże, O wychowaniu parafialnym, Kat, R. 8: 1964, nr 4, s. 152.

${ }^{15}$ Por. tenże, Teologia a potrzeby..., s. 243; tenże, Podstawy współczesnej..., s. 99.

${ }^{16}$ Por. tenże, Rozwój chrześcijańskiej koncepcji matzeństwa i rodziny, Roczniki Nauk Społecznych, t. 6: 1978, s. 75; tenże, Podstawy pedagogiczne rozwijania..., s. 96-97; tenże, Podstawy wspótczesnej..., s. 99; tenże, Teologia a potrzeby..., s. 243.

${ }^{17}$ Tenże, Propozycje pastoralno-pedagogiczne w sprawie odnowy życia zakonnego, w: Bielski T. (red.), Ku odnowie życia wewnętrznego. Powołanie człowieka, Poznań 1972, s. 238; por. 
Jezus wzywa człowieka do wewnętrznego odrodzenia się, do powtórnego narodzenia przez chrzest i działanie Ducha Świętego (,jeśli się ktoś nie narodzi z wody i z Ducha nie może wejść do Królestwa Bożego. [...] Trzeba wam się powtórnie narodzić” - J 3, 3-7). On sam jest „Nowym Człowiekiem (...wy wszyscy, którzy zostaliście ochrzczeni w Chrystusie, przyoblekliście się w Chrystusa" - Ga 3, 27) ${ }^{18}$. Jako Bóg - Człowiek i nasz Brat tworzy nową ludzkość - „lud Boży w Kościele, czyli w swoim Ciele Mistycznym" ${ }^{\prime \prime}$.

Poprzez dzieło wcielenia i odkupienia w Chrystusie zasada chrystocentryzmu ogarnia źródło i cel wychowania chrześcijańskiego ${ }^{20}$. Chrystus bowiem, ,jest Alfą i Omegą, Początkiem i Końcem"21. Zasada ta fascynuje osobą Chrystusa, który patrzy na człowieka z miłością przewyższającą wszelką wiedzę ${ }^{22}$. Występuje ona $\mathrm{w}$ całej religii chrześcijańskiej - w wierzeniach (dogmatyka), praktykach (liturgia), katechetyce, w moralności człowieka i jego przynależności do wspólnoty Kościoła (eklezjologia) ${ }^{23}$. Każdy chrześcijanin zatem „odkupiony przez Chrystusa ma się doskonalić na miarę wieku petności Chrystusowej, a to dzięki udzielaniu mu przez Kościół życia Chrystusowego, przez przepajanie życia duchem Chrystusowym, przez dawanie świadectwa życiem i naukąjedynemu Nauczycielowi - Chrystusowi" 24 .

Zasada chrystocentryzmu wymaga od wychowawców rozumienia woli i stworzonego przez Pana porządku. Wskazówek dotyczących każdej sfery życia (społecznego, rodzinnego, zawodowego itd.) muszą oni szukać w Chrystusowej Ewangelii i Tradycji Kościoła. Wszystko bowiem - „cała kultura i sztuka, życie codzienne, całe wychowanie chrześcijańskie powinno być przeniknięte duchem, przykładem i czynem Chrystusa"25. Chrystocentryzm kieruje więc działania wychowawcze ku Synowi Bożemu, pomaga kształtować Jego naśladowców

tenże, Rola uniwersytetów katolickich w historii nauki i oświaty, Zeszyty Naukowe Katolickiego Uniwersytetu Lubelskiego, R. 11: 1968, nr 3-4, s. 45.

${ }^{18}$ Por. tenże, Podstawy wspótczesnej..., s. 99.

${ }^{19}$ Tenże, Rozwój chrześcijańskiej koncepcji..., s. 74; por. Kerygmatyczna realizacja odnowy wychowania chrześcijańskiego, Roczniki Teologiczno-Kanoniczne, t. 14: 1967, z. 3, s. 78.

${ }^{20} \mathrm{~S}$. Kunowski wyróżnia chrystocentryzm liturgiczny, katechetyczny, kerygmatyczny (por. tenże, Teologia a potrzeby..., s. 243) oraz soteriologiczny, który przez Ducha Św. prowadzi wychowanka do chwały Bożej (por. tenże, Ogólne wskazania katechetyczne..., s. 146; tenże, Problemy wychowania chrześcijańskiego w świetle dokumentów Soboru Watykańskiego II, RTK, t. 18: 1971, z. 3, s. 173).

${ }^{21}$ Tenże, Problemy wychowania chrześcijańskiego..., s. 173; por. tenże, Założenia i aktualne potrzeby..., s. 233; tenże, Podstawy wychowania..., s. 211.

${ }^{22}$ Por. tenże, Problemy rozwojowe odnowy katechetycznej, STV, R. 5: 1967, s. 19; tenże, Podstawy wychowania..., s. 211.

${ }^{23}$ Por. tenże, Podstawy wspótczesnej..., s. 98-99.

${ }^{24} \mathrm{Za}$ : Deklaracja o wychowaniu chrześcijańskim-S. Kunowski, Podstawowe zasady wychowania..., s. 422.

${ }^{25}$ Tenże, Teologia a potrzeby..., s. 243; por. tenże, Założenia i aktualne potrzeby..., s. 227, 233. 
- pełnych chrześcijan ${ }^{26}$. Integruje wszystkie cele wychowania. Wykorzystując wskazane przez Chrystusa metody i środki edukacji, stawia na coraz doskonalsze poznanie i miłowanie Boga ${ }^{27}$.

Ta naczelna zasada w nauczaniu i wychowaniu duszpasterskim polega m.in. na posługiwaniu się w kazaniach przykładami życia Jezusa Chrystusa zaczerpniętymi z Ewangelii ${ }^{28}$. Ważne miejsce zajmuje ona w katechezie kerygmatycznej, która winna uobecniać „Chrystusa Ewangelicznego, prowadzić do Chrystusa Eucharystycznego oraz do Ducha Chrystusowego, rządzącego przez stałą obecność Ducha Świętego w Kościele i nastawić do świadczenia o Chrystusie w życiu codziennym oraz w świecie współczesnym"29. Świadectwem o szczególnym znaczeniu jest etyczne postępowanie człowieka, czyli wypełnianie nakazów moralnych pozostawionych przez Prawodawcę ${ }^{30}$. Ich wpajanie rozpoczyna się w rodzinie chrześcijańskiej, która buduje swe życie w oparciu o chrystocentryzm. Poprzez zrodzenie i wychowanie dzieci szerzy Królestwo Boże na ziemi. W jej normatywnym modelu naczelna zasada wynika z nauki Kościoła dotyczącej warunków założenia, celów, godności i wartości rodziny. Ta, mówiąc o nierozerwalności sakramentu małżeństwa, jego jedności, o miłości rodzinnej itp., czerpie z nauki Chrystusa i jej wiecznego przesłania ${ }^{31}$.

Chrystocentryzm jako nadrzędna zasada ,przepaja i uszlachetnia”32 całe wychowanie współczesnego człowieka. Wyraża się ona w podstawowych (kierowniczych) zasadach - personalizmie i humanizmie chrześcijańskim oraz w pozytywnym moralizmie, do którego bezpośrednio prowadzi. Chrystus bowiem „uzależniał zbawienie człowieka nie od słuchania tylko Jego nauki, lecz od spełniania dobrych uczynków, po których, jak po owocach, poznaje się wartość człowieka” ${ }^{33}$. Przestrzega On wyraźnie: „Nie każdy, który mi mówi: «Panie, Panie», wejdzie do królestwa niebieskiego, lecz ten, kto spełnia wolę mojego Ojca" (Mt 7, 21). Punktem wyjścia w zrozumieniu i wprowadzaniu w życie tych słów na zawsze pozostanie chrystocentryzm.

${ }^{26}$ Por. tenże, Podstawy wspótczesnej..., s. 98.

${ }^{27}$ Por. tenże, Podstawy wychowania..., s. 211; tenże, Pedagogiczne zadania moderatorów seminaryjnych, RTK, t. 22: 1975, z. 6, s. 105; tenże, Podstawowe zasady wychowania..., s. 422; tenże, Problemy rozwojowe odnowy..., s. 21.

28 Por. tenże, Potrzeby wychowania duszpastersko-katechetycznego, Kat, R. 6: 1962, nr 5, s. 271.

${ }^{29}$ Tenże, Ogólne wskazania katechetyczne..., s. 146; por. tenże, Problem duszpasterski..., s. 163.

${ }^{30}$ Por. tenże, Teologia a potrzeby..., s. 243; tenże, Kerygmatyczna realizacja odnowy..., s. 81.

${ }^{31}$ Por. tenże, Rozwój chrześcijańskiej koncepcji..., s. 74-75; tenże, Prawo ewolucji życia matżeńskiego, AK, R. 52: 1960, nr 307, s. 189.

32 Tenże, Pedagogiczne podstawy wychowania do pięknej miłości, AK, R. 51: 1959, nr 304, s. 188.

${ }^{33}$ Tenże, Podstawy pedagogiczne rozwijania..., s. 97; por. tenże, Teologia a potrzeby..., s. 243. 


\section{Moralizm chrześcijański wobec człowieka - sprawcy moralnego dobra}

Jezus Chrystus - moralny Prawodawca, poprawiając starotestamentalne prawo Mojżesza („oko za oko, ząb za ząb”), głosi ludziom: „Miłujcie waszych nieprzyjaciół i módlcie się za tych, którzy was prześladują" (Mt 5, 44). Nowe przykazanie miłości Boga i bliźniego („,miłuj swego bliźniego jak siebie samego" - Mt 19,19) staje się naczelnym prawem moralności. Z nauki tej wynika zasada moralizmu chrześcijańskiego dotycząca wychowania człowieka. Żąda ona nieustannego doskonalenia charakteru, woli i postaw dążeniowych nastawionych na radosne czynienie dobra w każdej dziedzinie życia ${ }^{34}$.

Moralizm Chrystusowy ${ }^{35}$ swoje źródło posiada w Piśmie Świętym, z którego czerpie teologia moralna oraz etyka normatywna tomizmu. Ta filozoficznoteologiczna nauka o moralnym postępowaniu człowieka głosi, że najwyższym i ostatecznym celem ludzkiego życia jest Nieskończone Dobro. Jemu podporządkowuje doczesne cele życia i kultury, do których człowiek zmierza świadomie i dobrowolnie. Tak więc etyka katolicka opiera się na religii i prawie naturalnym odczytywanym w głosie sumienia. Wpływa on na dążenie woli do dobra pod kierownictwem rozumu. Stanowi subiektywne kryterium postępowania, zgodnie ze słowami św. Pawła: „Wszystko bowiem, co się czyni niezgodnie z przekonaniem, jest grzechem" (Rz 14, 23). Świadome i dobrowolne naruszenie prawa, szczególnie zawartego w Dekalogu, jest odwróceniem się od Boga ${ }^{36}$.

Rozwój moralizmu chrześcijańskiego w aspekcie wychowania człowieka, jak twierdzi S. Kunowski, wiele zawdzięcza F. W. Foersterowi (1869-1966). Poprzez „nowe udowodnienie starych prawd" ${ }^{37}$ stawia on na usprawnianie i napełnianie religijnym duchem woli oraz charakteru. Proponuje wykorzystanie nadprzyrodzonych środków edukacji ${ }^{38}$. Współczesny moralizm Chrystusowy wyszedł poza ambonę i konfesjonał, przybierając maksymalistyczny i pozytywny charakter ${ }^{39}$.

${ }^{34}$ Por. tenże, Podstawy pedagogiczne rozwijania..., s. 97; tenże, Podstawy wychowania..., s. 211; tenże, Co wspótczesna pedagogika..., s. 244; tenże, Teologia a potrzeby..., s. 244; tenże, Podstawy wspótczesnej..., s. 99-100; tenże, Problemy rozwojowe odnowy..., s. 19.

${ }^{35}$ Sobór (Konstytucja duszpasterska o Kościele w świecie współczesnym - KDK 35) moralizm określa jako supernaturalistyczny. Wprowadza on w życie człowieka ład moralny. Przemienia je pod wpływem współdziałania z łaską, płynącego z żywej wiary w Syna Bożego - Zbawiciela - por. tenże, Problemy wychowania chrześcijańskiego..., s. 173; tenże, Ogólne wskazania katechetyczne..., s. 146.

${ }^{36}$ Por. tenże, Podstawy wspótczesnej..., s. 99-100.

${ }^{37}$ Tenże, Współczesne kierunki wychowania a wartości ewangeliczne [mps], Lublin 1939, s. 39.

${ }^{38}$ Por. F. W. Foerster, Religia a ksztatcenie charakteru. Dociekania psychologiczne i pedagogiczne wskazania, Poznań - Warszawa - Wilno - Lublin 1930; tenże, Szkoła i charakter. Przyczynek do pedagogiki postuszeństwa i do reformy karności w szkole, Warszawa-Lublin-Lódź-Kraków 1909.

${ }^{39}$ Por. S. Kunowski, Podstawy współczesnej..., s. 100. 
Zadaniem wszystkich wychowawców chrześcijańskich staje się „uporządkowanie warunków życia człowieka zgodnie z prawem moralnym Ewangelii, prawem miłości" 40 . Nakazuje ono człowiekowi czynienie moralnego dobra ,prawdziwie w miłości” (Ef 4, 15) ${ }^{41}$, skierowanie go na ludzi oraz Boga, co ,polega na spełnianiu Jego przykazań" (1 J 5, 3). Taka postawa prowadzi do osobowego uświęcania się ${ }^{42}$, gdyż życie w wierze i dobre uczynki chrześcijańskie zasługują na wieczną nagrodę. Świadomość ludzi, że do Boga ,idą wraz z nimi ich czyny” (Ap 14, 13) ${ }^{43}$, ułatwia współdziałanie z łaską i realizację przykazania miłości zarówno w kontemplacji, jak i w działaniu ${ }^{44}$. Prowadzi do sakramentalnej metanoi, która wpływa na zmianę obyczajów i doskonalenie się osób w przeświadczeniu, że „nie wystarczy wiedzieć, wierzyć i modlić się, ale trzeba czynić wolę Ojca niebieskiego"45.

Człowiek jest sprawcą zarówno dobra, jak i zła moralnego. Dobro go wewnętrznie ubogaca, a zło deprawuje, depersonalizuje i wynaturza ${ }^{46}$. Istnieje więc potrzeba kształtowania i duchowego usprawniania chrześcijańskiego charakteru wychowanków. Jego naturalną podstawę tworzą cnoty kardynalne. Roztropność usprawnia rozum praktyczny, czyli rozsądek. Sprawiedliwość (prawość) wzmacnia wolę. Umiarkowanie pozwala opanować władzę pożądawczą, a męstwo łamie przeszkody stojące na drodze do godziwego czynu moralnego. Równie ważną rolę pełnią tu cnoty wlane - wiara, nadzieja i miłośc ${ }^{47}$ oraz rady ewangeliczne: pokora, ubóstwo, czystość, prostota, stużba, pokuta, cierpienie i praca. Szczególnie z ostatnią wiąże się ofiarność, obowiazkowość i odpowiedzialność przed ludźmi, Bogiem i własnym sumieniem ${ }^{48}$. Poprzez ich pełną realizację osoba staje się wolna, szlachetna, moralnie dobra, a nawet doskonała ${ }^{49}$.

Zasada moralizmu chrześcijańskiego wskazuje wychowankowi szereg obowiązków moralnych pozostających pod kontrolą sumienia. Ma ona wymiar pozy-

${ }^{40}$ Tenże, Założenia i aktualne potrzeby..., s. 227.

${ }^{41}$ Por. tenże, Podstawy wychowania..., s. 211.

${ }^{42}$ Por. tenże, Propozycje pastoralno-pedagogiczne..., s. 238.

${ }^{43}$ Por. tenże, $O$ wychowaniu parafialnym..., s. 152; tenże, Wychowanie moralne jako istotny element wychowania chrześcijańskiego, w: Adamski F. (red.), Wychowanie $w$ rodzinie chrześcijańskiej, Warszawa 1973, s. 79; tenże, Rola wychowania moralnego w rodzinie chrześcijańskiej, ZNKUL, R. 14: 1971, nr 1, s. 66-67.

${ }^{44}$ Por. tenże, Kerygmatyczna realizacja odnowy..., s. 82; tenże, Problem duszpasterski..., s. 163.

${ }^{45}$ Tenże, Problemy rozwojowe odnowy..., s. 21; por. tenże, Rola uniwersytetów..., s. 45.

${ }^{46} \mathrm{Za}$ : K. Wojtyła, Ocena możliwości zbudowania etyki chrześcijańskiej przy założeniach systemu Maksa Schelera, Lublin 1959, s. 61-62; por. S. Kunowski, Etyka myślenia i działania technicznego, AK, R. 54: 1962, nr 319/320, s. 134.

${ }^{47}$ Por. S. Kunowski, Problem duszpasterski..., s. 163; tenże, Podstawy współczesnej..., s. 100; tenże, Etyka myślenia..., s. 133; tenże, Pedagogiczne zadania moderatorów..., s. 106.

${ }^{48}$ Por. tenże, Pedagogiczne zadania moderatorów..., s. 105-106; tenże, Podstawowe zasady wychowania..., s. 422; tenże, Podstawy dojrzałej osobowości..., s. 171; tenże, Etyka myślenia..., s. 132.

${ }^{49}$ Por. tenże, Etyka myślenia..., s. 133. 
tywny (nakazów sprawnego działania) jak i negatywny (zakazów wobec czynów moralnie złych, przekraczających ludzkie i Boże prawo ${ }^{50}$. Nastawiona jest na ocenę wartości moralnych i przyjmowanie ich drogą osobistego wyboru. Każe „oceniać wszystko w życiu i postępowaniu chrześcijanina w świetle nauki moralnej Chrystusa, w świetle przykazań Bożych Dekalogu oraz najwyższego przykazania czynnej, wyrażanej „całym swoim sercem, całą swoją duszą i całym swoim umysłem, miłości Boga i bliźniego" (Mt 22, 37-40)"51. Ocena moralna nie może sprowadzać się tylko do krytyki i potępiania zła. Winna ona prowadzić do czynów moralnie dobrych poprzez ukazywanie wzorów odnowy i doskonałości życia w Chrystusie ${ }^{52}$.

Stefan Kunowski przypomina, że moralizm chrześcijański „obejmuje swym zasięgiem wszystko, całe życie jednostek i społeczności, kulturę masową i technikę" ${ }^{53}$. Oceniając ład i nieład moralny, przedstawia praktyczne normy etyczne dobra - zła. Poddaje etyzacji i reguluje prawem „wszystkie zawiłości dróg życia ludzkiego" "54 każdą jego dziedzinę. Jako zasada wychowania uwzględniany musi być zarówno w edukacji rodzinnej, szkolnej, jak i w nauczaniu duszpasterskim ${ }^{55}$. Niemałą rolę odgrywa też „,przy kształceniu duchowym powołania kapłańskiego czy zakonnego" 56 . Kładzie więc nacisk na doskonalenie sprawności moralnych, na rozwój woli i chrześcijańskiego charakteru każdego wychowanka. Nastawia go na czynienie dobra z miłości i w miłości Boga oraz bliźniego.

\section{Zasada personalizmu podstawą społeczno-moralnego wychowania osoby}

Tradycja i cywilizacja chrześcijańska oparte są o poglądy personalistyczne ${ }^{57}$, które wywodzą się z Ewangelii. Chrystus daje nam przykład właściwego traktowania osoby ludzkiej, oddając należny jej szacunek. Docenia dziecko, młodzieńca, kobietę, mężczyznę, grzesznika, a nawet zbrodniarza. Budzi w nich poczucie własnej wartości i godności dziecka Bożego, co wypływa z duchowych właściwości osoby oraz najwyższego przeznaczenia jej duszy ${ }^{58}$.

${ }^{50}$ Por. tenże, Rozwój chrześcijańskiej koncepcji..., s. 52, 90.

${ }^{51}$ Tenże, Podstawy wychowania..., s. 211; por. tenże, Podstawowe zasady wychowania..., s. 422.

${ }^{52}$ Por. tenże, Podstawy wychowania..., s. 211.

${ }_{53}^{5}$ Tenże, Rola wychowania moralnego..., s. 67.

${ }^{54}$ Tenże, Założenia i aktualne potrzeby..., s. 227; por. tamże, s. 233.

${ }^{55}$ Por. tenże, Prawo ewolucji..., s. 189; tenże, Rola wychowania moralnego..., s. 67; tenże, Potrzeby wychowania..., s. 271; tenże, Podstawowe zasady wychowania..., s. 422.

${ }^{56}$ Tenże, Podstawy wspótczesnej..., s. 100.

${ }^{57}$ Por. tenże, U podstaw socjologizmu pedagogicznego, AK, R. 39: 1947, nr 254, s. 367; tenże, Współczesne kierunki wychowania... [mps], s. 37.

${ }^{58}$ Por. tenże, Podstawy współczesnej..., s. 101; tenże, Założenia i aktualne potrzeby..., s. 226. 
Pojęcie osoby (persona) zawdzięczamy Boecjuszowi, który w VI w. przeniósł je z Osób Boskich Trójcy św. na człowieka - obraz i podobieństwo Boże. Określił ją jako ,indywidualną substancję rozumną” (persona est rationalis naturae individua substantia). Definicja ta ukazuje człowieka jako złożoność duszy i ciała, która daje mu niepowtarzalne, indywidualne cechy. Istotę osoby stanowi górująca nad ciałem substancjalna dusza wraz z jej rozumnością̨ ${ }^{59}$ Ożywia ona ciało, wyraża się przez umysł i duchowość, która stanowi o życiu wewnętrznym człowieka (twórczość kulturalna, procesy poznawcze, dążenie do wartości i ideałów, moralność i religijność $)^{60}$.

Z teorii hilemorfizmu Boecjusza skorzystał św. Tomasz z Akwinu, podkreślając, że osoba ludzka jest trwaniem rozumnej natury. Jest ona tym, co najdoskonalsze wśród całego stworzenia. Naukę tę pogłębiono w XIX w. Założyciel zakonu Zmartwychwstańców w Polsce - o. Piotr Semeneńko pisał: „Natura jest tym, co mamy, osoba jest tym, czym jesteśmy. Osoba człowieka jest poza naturą ludzka, to jego $j a$, sam człowiek w sobie" ${ }^{\prime}$. W XX w. filozofię osoby aktualizuja i rozwijają twórcy ruchu personalistycznego - E. Mounier (1905-1950) i J. Maritain (1882-1973). Pierwszy z nich, w oparciu o poglądy św. Augustyna, twierdzi, że osoba ,jest punktem wyjścia w realizowaniu swej obecności w trzech wymiarach" 62 - wcielenia (w dół), wezwania (w górę) i uczestnictwa (wszerz). Przeciwstawia się ona osobowości ${ }^{63}$. Dla J. Maritain'a rozumna i społeczna osoba w jej ujęciu tomistycznym, ,jest punktem, z którego można dojść albo do indywidualności, albo do osobowości jednoczonej na drodze poznania i miłości z Bogiem" ${ }^{64}$. Prawdziwa osobowość, drogą miłości Boga i bliźniego, prawdy, dobra i piękna, dąży do mistycznego zjednoczenia z Panem w Trójcy Świętej ${ }^{65}$.

Zasadę personalizmu Chrystusowego adaptuje wychowanie chrześcijańskie. Na polski grunt przenoszą ją m.in. K. Górski (ujęcie intelektualno-tomistyczne) oraz A. Niesiołowski (ujęcie woluntarystyczno-augustyńskie) ${ }^{66}$. Zintegrowany rozwój osoby wszyscy autorzy wyprowadzają z duchowości duszy ludzkiej, która rozwija się już od poczęcia ${ }^{67}$. Ona to, za pomocą wartościowania wynikającego z władz rozumu i woli, winna panować nad cielesnością ${ }^{68}$. Ożywiając wszystkie

${ }^{59}$ Por. tamże; tenże, Współczesne kierunki wychowania... [mps], s. 37.
${ }^{60}$ Por. tenże, Boży dar życia ludzkiego a wychowanie człowieka, AK, R. 52: 1960, nr 209, s. 67.
${ }^{61}$ Za: Ks. Smolikowski, Ks. Piotr Semeneńko jako filozof, asceta i mistyk, Chicago 1921; s. B. Żulińska, Ku zmartwychwstaniu - problemy pedagogiczne, Toronto 1950; S. Kunowski, Podstawy współczesnej..., s. 101-102.

${ }^{62}$ S. Kunowski, Rozwój chrześcijańskiej koncepcji..., s. 55.

${ }^{63}$ Por. tamże; S. Kunowski, Podstawy wspótczesnej..., s. 102.

${ }^{64}$ Tenże, Rozwój chrześcijańskiej koncepcji..., s. 56.

${ }^{65}$ Por. tenże, Podstawy współczesnej..., s. 102.

${ }^{66}$ Por. tenże, Problematyka współczesnych..., s. 48-52.

${ }^{67}$ Por. tenże, Podstawy pedagogiczne rozwijania..., s. 69.

${ }^{68}$ Por. tenże, Aktualności pedagogiki..., s. 453; tenże, Współczesne prąy i kierunki w psychologii rozwojowej oraz pedagogicznej, Roczniki Filozoficzne, t. 13: 1965, z. 4, s. 69. 
warstwy rozwojowe ${ }^{69}$, prowadzi życie wewnętrzne człowieka ku chrześcijańskiej doskonałości. Dzięki duszy staje się ona ,jakby kwiatem długiego procesu rozwojowego i procesu wychowania" ${ }^{70}$ osoby jako indywidualności wolnej, rozumnej, odpowiedzialnej, posiadającej zarówno obowiązki, jak i prawa.

Zasada personalizmu chrześcijańskiego daje człowiekowi prawo do wszechstronnego, pełnego rozwoju osobowości ${ }^{71}$. Wpływa na świadome i dobrowolne dążenie do Chrystusowej doskonałości ${ }^{72}$. Uspołecznia osobę, zachowując zarazem jej indywidualność. Nastawia na współpracę z łaską, na miłość Boga, bliźniego i zdrową miłość samego siebie. Nie pozwala utracić „nigdy z oczu rozwijania się i doskonalenia samodzielności własnego $j a$, własnej jaźni i osobowości psychicznej, dochodzącej do swej dojrzałości jako całość" ${ }^{73}$. Człowiek dociera do niej zarówno poprzez naturalny rozwój, jak i duchowe doskonalenie się ${ }^{74}$ oparte na niezniszczalnych przymiotach osoby, które mocno akcentuje zasada personalizmu. Zakłada ona, że każdy człowiek zasługuje na poszanowanie swej godności i ogromnej wartości. Wiąże się z prawem osób do szacunku wobec ich wrodzonych i nabytych cech, wobec samodzielnej aktywności życiowej, która wynika $\mathrm{z}$ wewnętrznej wolności ${ }^{75}$.

Swą godność osoba uzyskuje poprzez fakt dziecięctwa i synostwa Bożego („,zostaliśmy nazwani dziećmi Bożymi i rzeczywiście nimi jesteśmy” - $1 \mathrm{~J} 3,1$ ). Dzięki niemu, świadoma swego powołania życiowego, zmierza ona do dojrzałej osobowości ${ }^{76}$ i do zbawienia. Dotyczy to każdej osoby bez względu na wiek („Dopuśćcie dzieci i nie przeszkadzajcie im przyjść do Mnie” - Mt 19, 14), płeć (np. rozmowa z Samarytanką), na stan społeczny (np. uzdrowienie sługi Setnika), bez względu na pochodzenie czy narodowość. Św. Paweł mówi: „Nie ma już Żyda ani poganina, nie ma już niewolnika ani człowieka wolnego, nie ma już mężczy-

${ }^{69}$ Por. tenże, Boży dar życia..., s. 77.

${ }^{70}$ Tenże, Podstawy pedagogiczne rozwijania..., s. 67.

${ }^{71}$ Tenże, Wplyw techniki na osobowość czlowieka, ZNKUL, R. 6: 1963, nr 4, s. 43.

${ }^{72}$ Por. tenże, Co wspótczesna pedagogika..., s. 244; tenże, O wychowaniu parafialnym..., s. 152; tenże, Założenia i aktualne potrzeby..., s. 233.

${ }^{73}$ Tenże, Podstawy dojrzałej osobowości..., s. 170-171; por. tenże, Współczesne kierunki wychowania... [mps], s. 39.

${ }^{74}$ Por. tenże, Podstawy pedagogiczne rozwijania..., s. 71. S. Kunowski podkreśla, że chrześcijańska dojrzałość duchowa nieustannie zagrożona jest grzechem, który oddala człowieka od Boga. Wiąże się on z sytuacjami, gdy cielesność próbuje zająć miejsce lub podporządkować sobie duchowość. Równie niebezpieczne jest „wyodrębnienie się duchowości i jej oderwanie się od wypartej do podświadomości sfery prywatnej seksualności i cielesności” - tenże, Podstawy dojrzałej osobowości..., s. 167.

${ }^{75}$ Por. tenże, Co współczesna pedagogika..., s. 244; tenże, Problem duszpasterski..., s. 163; tenże, Problematyka współczesnych..., s. 68; tenże, Podstawy współczesnej..., s. 101; tenże, Etyka myślenia..., s. 134; tenże, Podstawowe zasady wychowania..., s. 422; tenże, Problemy rozwojowe odnowy..., s. 19; tenże, Pedagogiczne zadania moderatorów..., s. 106.

${ }^{76}$ Por. tenże, Propozycje pastoralno-pedagogiczne..., s. 238; tenże, Rozwój chrześcijańskiej koncepcji..., s. 52; tenże, Wychowanie autentycznego człowieka..., s. 197. 
zny ani kobiety, wszyscy bowiem jesteście kimś jednym w Chrystusie Jezusie" $(\mathrm{Ga} 3,28)^{77}$. On odkupił duszę ludzka, która w głównej mierze świadczy o godności osoby. Dusza przewyższa wszelkie ziemskie skarby. „Cóż bowiem za korzyść stanowi dla człowieka zyskać świat cały, a swoją duszę utracić? Bo cóż może dać człowiek w zamian za swoją duszę?" (Mk 8, 36-37; Mt 16, 26) ${ }^{78}$. Stanowi ona najwyższa, nieśmiertelną wartość, która podczas ziemskiego życia może dążyć tak do zbawienia w stanie łaski, jak i do potępienia w stanie grzechu śmiertelnego ${ }^{79}$.

Zasada personalizmu chrześcijańskiego chroni człowieka przed ostateczną tragedią. Korzystając z dotychczasowego dorobku myśli filozoficznej (m.in. tomizm, augustynizm), integruje i rozwija cechy duchowości osoby. (1) Na ich czele stoi rozumność, czyli zdolność „do obiektywnie prawdziwego poznania na podstawie materiału zmysłowego z obserwacji empirycznej oraz na podstawie intuicji czynnego umysłu i abstrakcji pojęciowej, dzięki czemu ze świadectwa świata i natury dochodzi do poznania Stwórcy"80. (2) Zdolność do wartościowania i oceny każe osobie dążyć do najwyższych ideałów Dobra, Prawdy, Piękna i Świętości. Pozwala umiłować je i żyć nimi. (3) Twórcza aktywność powiększająca wspólne dobro wiąże się z pełną (4) odpowiedzialnościa moralno-społeczną za siebie i innych. Kulturalnym, odkrywczym i wynalazczym uszlachetnieniem materii winno kierować prawe sumienie współpracujące ze stwórczym dziełem Boga. (5) Metafizyczna otwartość jest wyjściem na spotkanie z Panem, poszukiwaniem, poznaniem i coraz większym umiłowaniem Osobowego Boga ${ }^{81}$.

Personalistyczne poszanowanie godności osoby wyraża się szacunkiem dla wolności jej decyzji dotyczących dążeń i działań (Chrystus proponuje: „Jeśli kto chce pójść za Mną" - Mt 16, 24) ${ }^{82}$. Daje prawo do pełnej samodzielności we współpracy z łaską (podstawa zbawienia) oraz do samostanowienia, które wymaga poszanowania wolności woli ${ }^{83}$. Chrześcijańska wolność wynika z Bożej prawdy, którą głosi Zbawiciel: „poznacie prawdę, a prawda was wyzwoli” (J 8, 32). Św. Paweł przestrzega jednak: „Wszystko wolno, ale nie wszystko przynosi korzyść. Wszystko wolno, ale nie wszystko buduje” (Kor 10, 23). Ludziom „powołanym do wolności radzi: Tylko nie bierzcie tej zachęty do hołdowania ciału, wręcz przeciwnie, miłością ożywieni służcie sobie wzajemnie" (Ga 5, 13). Problem wolności chrześcijańskiej nakłada więc na człowieka „odpowiedzialność

${ }^{77}$ Por. tenże, Teologia a potrzeby..., s. 244; tenże, Podstawy wychowania..., s. 212; tenże, Podstawy pedagogiczne rozwijania..., s. 98.

${ }^{78}$ Por. tenże, Podstawy wychowania..., s. 212; tenże, Podstawy pedagogiczne rozwijania..., s. 98; tenże, Podstawy wspótczesnej..., s. 101.

${ }^{79}$ Por. tenże, Współczesne kierunki wychowania... [mps], s. 37.

${ }^{80}$ Tenże, Podstawy pedagogiczne rozwijania..., s. 76.

${ }^{81}$ Por. tenże, Podstawy pedagogiczne rozwijania..., s. 76-77; tenże, Etyka myślenia ..., s. 135; tenże, Pedagogiczne podstawy..., s. 191; tenże, Współczesne kierunki wychowania... [mps], s. 38.

${ }^{82}$ Por. tenże, Podstawy wychowania ..., s. 212; tenże, Podstawy pedagogiczne rozwijania..., s. 98.

${ }^{83}$ Por. tenże, Współczesne kierunki wychowania... [mps], s. 38. 
za nią, by nie było jej nadużycia" ${ }^{84}$. Ograniczenie własnej wolności wiąże się z dobrem i miłością bliźniego, z przestrzeganiem przysługujących mu praw.

Każda osoba bowiem, jako istota wolna i rozumna, posiada prawa, które należy bezwzględnie szanować ${ }^{85}$. Ich opracowanie, z uwzględnieniem dzieci, młodzieży, ludzi pracy i kobiet, przypisuje się J. Maritain'owi. Jego założenia wykorzystano w międzynarodowych dokumentach ONZ - Powszechnej Deklaracji Praw Człowieka (1948) i w Deklaracji Praw Dziecka (1959) ${ }^{86}$. Naukę o prawach osoby ludzkiej rozwinął Jan XXIII w encyklikach Mater et Magistra (1961) oraz Pacem in terris (1963). Przedstawia on: 1) prawo do godnego życia, w którym nie może zabraknać żywności, odzieży, mieszkania, możliwości wypoczynku, opieki zdrowotnej czy ubezpieczeń społecznych; 2) prawo do korzystania z wartości etycznych i kulturalnych (szacunek, dobra opinia, wolność w poszukiwaniu prawdy i wypowiadaniu poglądów, swoboda twórczości); 3) prawo do prywatnego i publicznego oddawania czci Bogu, zgodnie z prawym sumieniem; 4) prawo do samodzielnego wyboru stanu oraz wolnego życia rodziny i wychowania dzieci; 5) prawo do pracy i godziwej zapłaty, do posiadania dóbr i środków ich wytwarzania; 6) prawa obywatela do zrzeszania się, migracji, do udziału w życiu społecznym, do ochrony praw ${ }^{87}$.

Praw osoby strzegą również dokumenty Vaticanum II, uwzględniające zasady personalizmu teocentrycznego. Prawdziwa wolność człowieka jest tu naczelnym celem życia ${ }^{88}$, dlatego bronią one wolności sumienia ${ }^{89} \mathrm{i} \mathrm{religii}^{90}$. Kładą nacisk na wolność badań i dostęp do słusznej informacji ${ }^{91}$. Ukazują szacunek dla Kościołów odłączonych ${ }^{92}$ i religii niechrześcijańskich ${ }^{93}$. Odrzucają dyskryminację rasy, religii i pochodzenia społecznego ${ }^{94}$. Dają osobie prawo do prawdziwego wychowania ${ }^{95}$ i pełnego rozwoju ${ }^{96}$. Prawdziwie ludzką formację młodzieży ${ }^{97}$ wiążą z wolnością wyboru szkół ${ }^{98}$ i uwzględnianiem życzeń rodziców ${ }^{99}$.

${ }^{84}$ Tenże, Kerygmatyczna realizacja odnowy..., s. 85.

${ }^{85}$ Por. tamże, s. 84; tenże, Rola uniwersytetów..., s. 45.

${ }^{86}$ Por. tenże, Podstawy współczesnej..., s. 102; tenże, Etyka myślenia ..., s. 134; tenże, Deklaracja Praw Dziecka, w: Encyklopedia katolicka t. 3, Lublin 1976, kol. 1118.

${ }^{87}$ Jan XXIII, Pacem in terris, Kraków 1963, s. 9-13; por. S. Kunowski, Podstawy współczesnej..., s. 103.

${ }^{88}$ Por. DWCH, nr 1.

${ }^{89}$ Por. DWCH, nr 8.

${ }^{90}$ Por. DWCH, nr 7, Deklaracja o wolności religijnej (DWR, nr 2).

${ }^{91}$ Por. Inter mirifica - Dekret o środkach społecznego przekazu (DSP, nr 12).

${ }^{92}$ Por. Dekret o ekumenizmie (DE, nr 3).

${ }_{93}$ Por. Dekret o stosunku Kościoła do religii niechrześcijańskiej (DRN, nr 2).

${ }^{94}$ Por. DRN, nr 5.

${ }^{95}$ Por. DWCH, nr 1.

${ }^{96}$ Por. DWCH, nr 2.

${ }^{97}$ Por. DWCH, nr 8.

${ }^{98}$ Por. DWCH, nr 6.

${ }^{99}$ Por. DWCH, nr 3; por. S. Kunowski, Problemy wychowania chrześcijańskiego..., s. 174; tenże, Podstawowe zasady wychowania..., s. 422. 
Zasada personalizmu chrześcijańskiego wymaga stworzenia odpowiednich warunków dla szeroko pojętej edukacji człowieka. Jej przebieg opiera się na różnorodności form i metod pracy dostosowanych do indywidualnych cech wychowanka ${ }^{100}$. Kładzie nacisk na odpowiednią postawę wychowawcy ${ }^{101}$ zarówno w imperium surowości i karania, ,jak też w jego postawie pietas, która musi się liczyć z ludzką stroną wychowanka jako rozwijającą się do pełni praw osobą"102. Ta „domaga się delikatności, taktu, liczenia się z wolnością decyzji i dobrowolnością"103. Nie ukrywa potrzeb miłości, radości, uśmiechu i życzliwości ze strony innych. Woła o pomoc, radę i wskazówki życiowe. Pragnie poczucia bezpieczeństwa, pewności i wierności. Nie uznaje poniżania swej godności, np. poprzez ironię $e^{104}$.

Zasada personalizmu chrześcijańskiego obejmuje całe wychowanie człowie$\mathrm{ka}$ - rodzinne ${ }^{105}$, szkolne i duszpasterskie ${ }^{106}$. Występuje ona w przygotowaniu do życia w rodzinie, jak też w formacji kapłańskiej i zakonnej. Nie omija wychowania do pracy zawodowej, które zawiera w sobie problem postępu technicznonaukowego i produkcji wobec dobra rozwoju osoby ${ }^{107}$. Zasadę tę wychowawcy powinni realizować w sposób świadomy i stopniowo uświadamiać ją wychowankom $^{108}$, którzy rozwijając w sobie godność osobistą, przygotowują się do rozumnego korzystania z przysługujących osobie praw. Muszą oni wiedzieć, że prawo do wolności i samodzielności nie zwalnia od współdziałania z wychowawcami i posłuszeństwa wobec autorytetu. Tylko w ten sposób mogą wejść na właściwą drogę chrześcijańskiego samowychowania, wewnętrznego doskonalenia się przez całe życie ${ }^{109}$.

\section{Humanizm zasadą chrześcijańskiej realizacji dobra w milości}

Z zasadami moralizmu i personalizmu ściśle wiąże się zasada humanizmu chrześcijańskiego. Pochodzi ona od Chrystusa, który dla dobra ludzi przybył na ziemię, by odkupić świat od grzechu - „Tak bowiem Bóg umiłował świat, że Syna swego Jednorodzonego dał, aby każdy kto w Niego wierzy nie zginął, ale

\footnotetext{
${ }^{100}$ Por. tenże, Etyka myślenia ..., s. 136; tenże, Problemy rozwojowe odnowy..., s. 19.

${ }^{101}$ Por. tenże, Podstawy pedagogiczne rozwijania..., s. 98.

102 Tenże, Kerygmatyczna realizacja odnowy..., s. 84.

${ }^{103}$ Tenże, Podstawy pedagogiczne rozwijania..., s. 98.

104 Por. tenże, Problemy wychowawcze chrześcijańskiego życia wewnętrznego, RTK, t. 20:

${ }^{105}$ Por. tenże, Prawo ewolucji..., s. 184.

106 Por. tenże, Potrzeby wychowania ..., s. 271.

${ }^{107}$ Por. tenże, Etyka myślenia..., s. 124.

${ }^{108}$ Por. tenże, Ogólne wskazania katechetyczne..., s. 146.

${ }^{109}$ Por. tenże, Propozycje pastoralno-pedagogiczne..., s. 245.
} 1973, z. 6, s. 263, 271. 
miał życie wieczne" (J 3, 16). Jako humanizm prawdy o Wcieleniu i Krzyżu ${ }^{110}$ dotyczy ,niesienia pomocy i świadczenia dobra drugiemu człowiekowi” ${ }^{\prime 11}$. Wynika z ofiarnej miłości (caritas), która obejmuje wszystkich ludzi, szczególnie pokrzywdzonych i potrzebujących pomocy. Daje praktyczne wskazówki dla realizacji dobra i sprawiedliwego zaspokajania potrzeb ludzkich w imię miłości Boga i bliźniego ${ }^{112}$.

Humanizm ewangeliczny ${ }^{113}$ „stoi pod znakiem przyszłości” ${ }^{114}$ życia kulturalnego, społeczno-ekonomicznego, politycznego i międzynarodowego pokoju ${ }^{115}$. Musi więc być wchłonięty przez wychowanie chrześcijańskie i stać na straży wszechstronnych dóbr rozwijającego się człowieka ${ }^{116}$.

Zasada humanizmu wszystkie wartości ewangeliczne podporządkowuje dobru człowieka, dla którego objawiona została religia - „To szabat został ustanowiony dla człowieka, nie człowiek dla szabatu" (Mk 2, 27) ${ }^{117}$. Dobru człowieka służy łaska Boża. Ona swą wyzwoleńczą, leczniczą i uszczęśliwiającą mocą obejmuje wszelkie pragnienia serca i duszy, uwalnia od grzechu. Prowadzi do najwyższego dobra duchowego - do zbawienia.

Chrystus, który przeszedł „dobrze czyniąc i uzdrawiając wszystkich” (Dz 10, 38) ${ }^{118}$, przynosi człowiekowi szczęście wieczne (,Ja przyszedłem po to, aby [owce] miały życie i miały je w obfitości" - J 10, 10); daje pomoc w trudach życia („Przyjdźcie do mnie wszyscy, którzy utrudzeni i obciążeni jesteście, a Ja was pokrzepię" - Mt 11,28). Wyzwala ludzi od błędu (,i poznacie prawdę, a prawda was wyzwoli” - J 8, 32); przynosi im pokój („Pokój zostawiam wam, pokój mój daję wam” - J 14, 27). Przede wszystkim uczy i wymaga miłości - „To wam przykazuję, abyście się wzajemnie miłowali” $(\mathrm{J} 15,17)^{119}$.

Zasada humanizmu chrześcijańskiego, kładąc nacisk na dobro osoby, kieruje jej aktywność „ku dobru wspólnemu, z którego to dobra sama jednostka korzysta" ${ }^{120}$. Nastawienie teocentryczne wskazuje na realizację zarówno doczesnego,

${ }^{110}$ Zasady humanizmu chrześcijańskiego uzupełnia wychowanie laickie, które nie ogarnia całej prawdy i ogranicza dobro człowieka - por. tenże, Aktualności pedagogiki..., s. 459.

111 Tenże, Podstawy pedagogiczne rozwijania..., s. 98.

112 Por. tenże, Podstawy wspótczesnej..., s. 103-104; tenże, Teologia a potrzeby..., s. 245; tenże, Rola uniwersytetów..., s. 45; tenże, Wychowanie autentycznego człowieka..., s. 197.

113 Por. Pedagogiczne zadania moderatorów..., s. 105; tenże, Problematyka współczesnych..., s. 107.

${ }^{114}$ Tenże, Problemy wychowania chrześcijańskiego..., s. 174.

${ }^{115}$ Por. tamże (KDK 55-56, 62).

${ }^{116}$ Por. S. Kunowski, Aktualności pedagogiki..., s. 458.

${ }^{117}$ Por. tenże, Podstawy wychowania..., s. 212; tenże, Założenia i aktualne potrzeby..., s. 226; tenże, Podstawy współczesnej..., s. 103; tenże, Podstawy pedagogiczne rozwijania..., s. 98.

118 Por. tenże, Podstawy pedagogiczne rozwijania..., s. 98; tenże, Teologia a potrzeby..., s. 224; tenże, Podstawy wychowania..., s. 212.

${ }^{119}$ Por. tenże, Teologia a potrzeby..., s. 244.

${ }^{120}$ Tenże, Podstawy dojrzałej osobowości..., s. 17; por. tenże, Podstawowe zasady wychowania..., s. 422. 
jak i wiecznego dobra. Osiagnąć je można jedynie poprzez społeczne współdziałanie i odpowiedzialność rodziny, państwa, Kościoła i całej ludzkości ${ }^{121}$. Podstawa „uczestnictwa w życiu wspólnot chrześcijańskich tak doczesnych i ziemskich, jak też i w obcowaniu świętych"122, jest ofiara i czynna miłość bliźniego. Człowiek, „żyjąc prawdziwie w miłości” $(\mathrm{Ef} 4,15)^{123}$, winien realizować chrześcijańską caritas poprzez dzieła charytatywne ${ }^{124}$ : względem duszy, wynikające z siedmiu uczynków miłosierdzia (grzeszących upominać; nieumiejętnych pouczać; wątpiącym dobrze radzić; strapionych pocieszać; cierpliwie znosić krzywdy; chętnie darować urazy; modlić się za żywych i umarłych) oraz względem ciała (głodnych nakarmić; spragnionych napoić; nagich przyodziać; podróżnych przyjąć do domu, więźniów pocieszać; chorych odwiedzać; grzebać zmarłych) ${ }^{125}$. Za obojętność na potrzeby innych Chrystus przewiduje karę: „Zaprawdę powiadam wam: «Wszystko, czego nie uczyniliście jednemu z tych najmniejszych, tegoście i Mnie nie uczynili». I pójdą ci na mękę wieczną, sprawiedliwi zaś do życia wiecznego" $(\text { Mt 25, 45) })^{126}$.

Zasada humanizmu chrześcijańskiego reaguje na zmiany rzeczywistości, nawiązuje do aktualnych potrzeb epoki. Wypływając z miłości Boga i bliźniego, obejmuje dobro całego człowieka. Dąży do zaspokojenia jego potrzeb duchowych, społecznych, psychicznych, biologicznych i materialnych. One wszystkie wiążą się z potrzebą wszechstronnego rozwoju ${ }^{127}$, która zawiera w sobie zarówno zdrowie i tężyznę fizyczna, wykształcenie i pracę, jak i kulturę oraz szczęście ${ }^{128}$. Jej zaspokajanie należy do praw osoby, o których rozprawia wiele społecznych dokumentów Kościoła (m.in. Jan XXIII, Pacem in terris; Paweł VI, Octogessima adveniens; KDK) ${ }^{129}$.

Humanistyczna realizacja praw wynikających z ludzkich potrzeb umożliwia „naturalny rozwój wewnętrzny człowieka” ${ }^{130}$. Przeobraża go i doskonali,

${ }^{121}$ Por. tenże, Podstawy pedagogiczne rozwijania..., s. 98; tenże, Etyka myślenia..., s. 134.

${ }^{122}$ Tenże, Propozycje pastoralno-pedagogiczne..., s. 238.

${ }^{123}$ Por. tenże, Podstawy współczesnej..., s. 104.

${ }^{124}$ Zasada humanizmu chrześcijańskiego nakłada na Kościół obowiązek pomocy wszystkim potrzebującym, np. prowadzenie szpitali, domów dziecka, domów opieki społecznej (DWCH 9) por. tenże, Podstawowe zasady wychowania ..., s. 422; tenże, Podstawy wspótczesnej ..., s. 104.

${ }^{125}$ Por. tenże, Podstawy współczesnej..., s. 103; tenże, Podstawy pedagogiczne rozwijania..., s. 98; tenże, $O$ wychowaniu parafialnym..., s. 153.

${ }^{126}$ Por. tenże, Teologia a potrzeby..., s. 244.

${ }^{127}$ Por. tenże, Ogólne wskazania katechetyczne..., s. 146; tenże, Pedagogiczne zadania moderatorów..., s. 106; tenże, Uwarunkowania edukacji wspólnotowej w duchu sprawiedliwości i pokoju, w: ks. J. Krucina (red.), Dei Virtus. Kardynałowi Bolesławowi Kominkowi w hołdzie, Wrocław 1974, s. 133; tenże, Założenia i aktualne potrzeby..., s. 233.

${ }^{128}$ Por. tenże, Co współczesna pedagogika..., s. 244.

129 Por. tenże, Podstawy wspótczesnej..., s. 103, 104; tenże, Propozycje pastoralno-pedagogiczne..., s. 245; tenże, Co wspótczesna pedagogika..., s. 244; tenże, Problem duszpasterski..., s. 163 ; por. 5.3.1.

${ }^{130}$ S. Kunowski, Aktualności pedagogiki..., s. 457. 
zapewniając nadprzyrodzoną pomoc. „Bierze w obronę każdego człowieka pokrzywdzonego przez grzech pierworodny i grzech ustroju czy kultury i daje mu najpewniej to, co sam przy współpracy z łaską Bożą może zdobyć dla swego wszechstronnego szczęścia"131.

Tak więc humanizm chrześcijański, poprzez swój związek z religia, „ma być wszechstronnym rozwinięciem człowieczeństwa w jednostce"132. Tym samym posiada ogromne znaczenie wychowawcze. Ulepsza człowieka, czyni jego życie pogodnym i radosnym ${ }^{133}$. Znajduje zastosowanie w całej przestrzeni edukacyjnej. Jako zasada życia rodzinnego wskazuje na dobro małżonków i ich dzieci przez zaspokajanie potrzeb każdego członka rodziny ${ }^{134}$. W wychowaniu i nauczaniu szkolnym oraz duszpasterskim jej stosowanie polega m.in. na stawianiu wymagań adekwatnych do możliwości wychowanków ${ }^{135}$. Nie mogąc odrywać się od warunków współczesnego świata, zasada ta obejmuje też kształtowanie postaw ludzi pracy. Daje podstawy norm społeczno-etycznych w dziedzinie produkcji i postępu naukowo-technicznego. Dba o wspólne dobro w wymiarze „rodziny ludzkości"136. Dotyka dobra użytecznego, praktycznej prawdy, funkcjonalnego piękna oraz świętości chwały Bożej ${ }^{137}$. Humanizm chrześcijański nieustannie dąży do tego, by każdy człowiek „nawrócił się i żył”138 dla dobra swojego i innych ludzi. Jako zasada wychowania nie może oderwać się od pozostałych „odwiecznych idei wychowawczych"139. Wspólnie z nimi przeobraża i uzdrawia z natury egoistyczną osobę, rozwija najdoskonalsze strony jej wewnętrznej istoty ${ }^{140}$.

Wynikające $\mathrm{z}$ chrystocentryzmu idee ${ }^{141}$ muszą znaleźć swe zastosowanie $\mathrm{w}$ rodzinie, szkole, uniwersytecie ${ }^{142}$, w miejscu pracy oraz $\mathrm{w}$ działaniu wycho-

131 Tamże, s. 458.

${ }^{132}$ S. Kunowski, Co wspótczesna pedagogika..., s. 244.

${ }^{133}$ Por. tenże, Teologia a potrzeby..., s. 244; tenże, Problemy rozwojowe odnowy..., s. 19.

${ }^{134}$ Por. tenże, Prawo ewolucji..., s. 189.

${ }^{135}$ Por. tenże, Potrzeby wychowania..., s. 271.

${ }^{136}$ Tenże, Etyka myślenia..., s. 124.

${ }^{137}$ Por. tamże, s. 141.

${ }^{138}$ S. Kunowski, Aktualności pedagogiki..., s. 458.

${ }^{139}$ Tenże, Co wspótczesna pedagogika..., s. 244

${ }^{140}$ Por. tenże, Podstawy współczesnej..., s. 104.

${ }^{141}$ Podstawowe zasady chrystocentryzmu, moralizmu, personalizmu i humanizmu chrześcijańskiego S. Kunowski upodabnia do „czworga zwierzqt przed tronem Baranka (Obj 4, 6-7), które stały się emblematami Ewangelistów. Gdy więc chrystocentryzm niewątpliwie cechuje Ewangelię według św. Jana (orzeł w locie), moralizm zaś przebija u św. Mateusza (wół ofiarny), to znów personalizm da się wykryć u św. Marka (wolny lew), a humanizm wybitnie u św. Łukasza (oblicze człowieka)" - S. Kunowski, Kerygmatyczna realizacja odnowy..., s. 87.

${ }^{142}$ Por. tenże, Rola uniwersytetów..., s. 45. 
wawczym Kościoła ${ }^{143}$. Winny przenikać współczesną katechetykę ${ }^{144}$ oraz formację kapłańską i zakonną ${ }^{145}$. Szczególne znaczenie mają w przezwyciężaniu trudności współczesnego świata. Trzeba je więc - zdaniem Stefana Kunowskiego „nieustannie głosić, podawać do wiadomości, zasiewać, propagować, odświeżać i przypominać, co więcej, zasady te muszą być rozumnie przyswojone i wyuczone, utrwalone raz na zawsze, z wiarą przeżyte i wcielane w codzienny czyn"146. Wszystkim wychowankom stawiają one za przykład Chrystusa. On to pozostawił ludziom wspaniałą naukę moralną, przywrócił człowiekowi pełną godność, pokazał jak reagować na potrzeby innych. Wezwał wszystkich do wewnętrznego odrodzenia i powtórnego narodzenia ${ }^{147}$.

\section{Christian Upbringing Rules in the Light of Stefan Kunowski's Conception}

(Summary)

Basic principles of pedagogy are involved in the collection of rules which are necessary for the people's educating process. These general working principles ought to be obeyed by all the educators, regardless of the education's discipline.

The managerial rules of upbringing propagated by S. Kunowski derive from man's main aim (superior idea) as well as from the subject of education (broad development and spiritual transformation of nature). They are not different from the rules of Christianity as a whole, because were created and passed on in the Gospel by God's Son. Therefore, the central position among the rules belongs to Christ-centrism as a source and spirit of the rest of them. This is Christ-centrism which, together with moralistic approach, is connected to the super nature. Both of the rules appeal to man's goodwill. Personal approach and humanism result from humane nature created on the model of God, which lead to him. They are directed to free rational being as a social creature.

${ }^{143}$ Autor zwraca uwagę, że w wychowawczym działaniu Kościoła występują ,,różne odmiany chrystocentryzmu jak i moralizmu, zarówno odmiany personalizmu, jak i humanizmu chrześcijańskiego, różny zakres idei składowych w nich oraz różny stopień ich przeżycia" - tenże, Propozycje pastoralno-pedagogiczne..., s. 238.

${ }^{144}$ Por. S. Kunowski, Ogólne wskazania katechetyczne..., s. 146; tenże, O potrzebie naukowego wyodrębnienia wspótczesnej pedagogiki katolickiej, Kat, R. 2: 1958, nr 4, s. 293.

${ }^{145}$ Por. tenże, Propozycje pastoralno-pedagogiczne..., s. 239.

146 Tenże, Uwagi o technice wychowania, Roczniki Humanistyczne 1950, nr 2-3, s. $323-324$.

${ }^{147}$ Por. tenże, Podstawy współczesnej..., s. 99. 